University of New Hampshire

University of New Hampshire Scholars' Repository

7-17-2017

\title{
Resisting punitive school discipline: perspectives and practices of exemplary urban elementary teachers
}

\author{
Elyse Hambacher \\ University of New Hampshire, elyse.hambacher@unh.edu
}

Follow this and additional works at: https://scholars.unh.edu/educ_facpub

Part of the Education Commons

\section{Comments}

This is an Author's Original Manuscript of an article published by Taylor \& Francis in International Journal of Qualitative Studies in Education in 2017, available online: https://doi.org/10.1080/09518398.2017.1349958

\section{Recommended Citation}

Hambacher, Elyse, "Resisting punitive school discipline: perspectives and practices of exemplary urban elementary teachers" (2017). International Journal of Qualitative Studies in Education. 100.

https://scholars.unh.edu/educ_facpub/100

This Article is brought to you for free and open access by the Education at University of New Hampshire Scholars' Repository. It has been accepted for inclusion in Education Scholarship by an authorized administrator of University of New Hampshire Scholars' Repository. For more information, please contact Scholarly.Communication@unh.edu. 
Running head: RESISTING PUNITIVE SCHOOL DISCIPLINE

In addition to stark racial disparities in school achievement, research has consistently

revealed that students of color and those from low-income backgrounds are vulnerable to differential and disproportionate rates of punitive school disciplinary sanctions (Skiba, Michael, Nardo, \& Peterson, 2000; Skiba et al., 2011; Wallace et al., 2008). These studies highlight a racial discipline gap where black students in particular, experience more punitive discipline than any other racial group. Punitive practices such as suspensions and expulsions are common ways that schools respond to student behavior, despite the fact that they contribute to students losing instructional time, forming negative perceptions of school climate, disengaging, and dropping out of school (Brown \& Rodríguez, 2009; Gregory, Skiba, \& Noguera, 2010). Exclusionary discipline and its consequent labeling of certain students as troublemakers and non-achievers negatively impacts students' lives.

Evidence suggests that there is a connection between school-based exclusionary discipline practices and detrimental school and life outcomes, including involvement in the juvenile justice system (Losen, 2014; Skiba, Arredondo, \& Williams, 2014). For instance, black people constitute $13 \%$ percent of the US population, yet they make up $40 \%$ of all inmates in prison and $42 \%$ of the death row population. This progression from perceived "troublemaker" to incarcerated felon is referred to as the school-to-prison-pipeline (STPP) - a process that engenders negative life trajectories and social reproduction, as persistently disciplined students become less invested in school because they feel disconnected from the very institutions that are responsible for bolstering their success (Gregory, Skiba, \& Noguera, 2010).

While researchers have uncovered teacher stereotyping and differential treatment of students using quantitative measures as explanations for racial disproportionality in discipline 


\section{RESISTING PUNITIVE SCHOOL DISCIPLINE}

(Skiba et al., 2000; Wallace et al., 2008), less is known about the stances and practices of exemplary teachers in responding to issues of discipline. Examining highly effective teachers and how they respond to student behavior is crucial in the elementary grades where the initial identification of a child as a behavior problem is "a process ... that often traces back to children's earliest experiences at school” (Alexander, Entwisle, \& Kabbani, 2001, p. 763). Racial bias in school discipline is part of a broader discourse concerning institutional racism where the over-sanctioning of students of color is fueling the STPP by interpreting their behavior as deviant. With this in mind, the study aimed to address the research question: What are the perspectives and instructional practices of exemplary urban elementary teachers who do not use punitive discipline with their students?

\section{A Review of the Literature}

Despite seminal research on classroom management (Emmer, Evertson, \& Anderson, 1980; Brophy, 1988), differential and disproportionate rates of disciplinary practices for students of color persist. Researchers have found that teachers' racial bias influences their subjective interpretations of student behavior (e.g. Skiba et al., 2000; Skiba, et al., 2011) and show that students of color are given office referrals for subjectively defined behaviors such as "disrespect" and "excessive noise" whereas white students were referred less and for objective behavior (e.g., skipping class) (Skiba et al., 2000). As U.S. schools become increasingly diverse, the teaching force remains overly homogenous ( $82 \%$ white, monolingual, female, and middle class) (Goldring, Gray, \& Bitterman, 2013). Viewing the world through a White middle-class lens often leaves white teachers unconscious of how schools perpetuate racist practices, such as teachers interpreting the behaviors of their students of color as defiant and removing them from 


\section{RESISTING PUNITIVE SCHOOL DISCIPLINE}

the classroom. In fact, Ferguson (2001) found that teachers drew on racial stereotypes and fear, which fueled their interpretations of black students as defiant. When teachers who operate within dominant cultural norms single out children of color for violations of the dominant culture's implicit classroom codes, their expectations for behavior influence whether students are selected for discipline in the first place. Teachers' lack of support and care positions students as blameworthy for their behavior (Collins, 2011), yet some teachers are able to elicit cooperation and defuse behavior issues before they escalate (Gregory \& Weinstein, 2008). The remainder of this section explores the literature related to culturally responsive classroom management (CRCM) and culturally relevant critical teacher care (CRCTC) as a lens to view the complexity of student discipline.

Culturally responsive classroom management addresses "the need for teachers to develop the knowledge, skills, and predispositions to teach children from diverse, racial, ethnic, language, and social class backgrounds" (Weinstein, Curran, \& Tomlinson-Clarke, 2003, p. 56). To practice CRCM, Weinstein, Tomlinson-Clarke, and Curran (2004) suggest that teachers must develop: (a) recognition of one's own ethnocentrism and biases; (b) knowledge of students' cultural backgrounds; (c) understanding of the broader social, economic, and political context of our educational system; (d) ability and willingness to use culturally appropriate classroom management strategies; and (e) commitment to building caring classroom communities. These guiding principles can assist teachers in creating classroom environments in which students feel safe, respected, and a sense of personal responsibility as they interact with others.

Empirical studies have demonstrated the potential of CRCM in building positive classroom management and climate. For example, Brown's (2003) interview study found teachers were 


\section{RESISTING PUNITIVE SCHOOL DISCIPLINE}

assertive pedagogues who engaged in mutual respect with students and used culturally congruent communication styles. Author (2007) described the significance of relationship building by three effective novice teachers to establish CRCM in two predominantly African American lowincome schools. Using interviews and video observation, they found that the teachers began to develop relationships immediately_during the first two hours on the first day of school. The educators used a personal approach to teaching and set an important tone within minutes of meeting students through lessons about care, respect, and how to treat others. Teachers in these studies used insistence as a means to create a supportive psychological environment and to communicating their belief in students' success. Ullucci's (2009) study of six successful elementary teachers in urban schools showed that they established classroom norms that guided the learning environment, encouraged peers to talk with one another to solve issues that threatened the community, and used humor to redirect inappropriate behavior. Milner and Tenore's (2010) interview and observation study of one white and one black teacher corroborates previous CRCM studies and highlights that while teachers who share the same cultural background as their students may have an advantage over teachers teaching across racial differences, white teachers can overcome racial barriers to support build classroom community with their students of color.

Punitive disciplinary practices for students of color reinforces feelings of distrust and a lack of care (Kennedy-Lewis, Murphy, \& Grosland, 2014; Woods, 2008) and therefore suggests that a particular kind of care from their teachers is sorely needed. Drawing on critical race theory, care theory, and black teacher pedagogy, culturally relevant critical teacher care (CRCTC) aims to disrupt the notion of a colorblind understanding of teacher care (Roberts, 


\section{RESISTING PUNITIVE SCHOOL DISCIPLINE}

2010). CRCTC informs this study because it acknowledges race as playing a central role in the positioning of certain students as bad or disruptive. The eight secondary black teachers in Roberts' study acknowledged the presence of racism and hegemony that black children experience in all aspects of life and communicated care for students in ways that demonstrated political clarity. Bartolomé (2009) states that:

teachers working toward political clarity understand that they can either maintain the status quo, or they can work to transform the sociocultural reality at the classroom and school level so that the culture at this micro-level does not reflect macro-level inequalities, such as asymmetrical power relations that relegate certain cultural groups to a subordinate status. (p. 342)

Acosta's (2015) interview study of successful black educators also found that the teachers' enactments of care were connected to their understanding of the political, economic, and social inequities inhibiting them from a fuller humanity. Care was manifested in the teachers' sense of urgency to help students achieve, and they consistently communicated critical care in their belief of students' aptitudes and potential. Embedded in the literature on CRCTC is a liberatory pedagogy, or the pedagogy of people engaged in fighting their oppression to gain the power to control their own lives (Freire, 1993; hooks, 1994; Kincheloe, 2008). Teachers who enact a pedagogy of liberation view education as "the practice of freedom" and recognize "the forces that prevent individuals and groups from shaping the decisions that crucially affect their lives” (Kincheloe, 2008, p. 51). Indeed, teachers who enact CRCTC help foster students' resilience and sociopolitical consciousness.

CRCTC is not merely concerned with students' academic success but aims to nurture the 


\section{RESISTING PUNITIVE SCHOOL DISCIPLINE}

whole child. The literature on effective teaching for African American children highlights teachers who view themselves as othermothers - teachers who believe they are responsible for nurturing the psychoeducational needs of children who have for so long been viewed as deficient (Case, 1997; Collins, 1991; Foster, 1998). Othermothers use their classrooms as sites for social activism (Collins, 1991) by taking on roles as change agents who promote student empowerment and transformation. The caring of othermothers goes far beyond interpersonal caring - it is political in purpose and in practice (Beauboef-LaFontant, 2005).

The literature is replete with studies that document disproportionality in student discipline (e.g., Collins, 2011; Ferguson, 2001; Wallace et al., 2008). In 2013, Milner posed the question: Why are students of color still punished more severely and frequently than white students? The present study seeks to move beyond the question of why students of color are punished more severely and more often to understand the perspectives and practices of exemplary teachers who refuse to rely on punitive, reactive discipline.

\section{Methodology}

The study is undergirded by constructivism, the epistemological position that no single interpretation exists and meaning cannot be described as objective (Crotty, 1998). This paradigm is subsumed under an interpretivist theoretical perspective concerned with understanding human and social reality. An interpretivist perspective suits this study as it provides a foundation for understanding exemplary teachers' perspectives and practices related to student behavior. Ethnographic methods were used to investigate the teachers' sense making and social contexts in which their perspectives are constructed and enacted in their classrooms. The teachers are represented in separate case studies, which is a common methodological choice when the 


\section{RESISTING PUNITIVE SCHOOL DISCIPLINE}

research addresses an explanatory question related to contemporary, real-life situations. Cases are particularly suited for research that aims to illuminate particulars in a given context (Yin, 2009). In this study, the goal is to gain an in-depth understanding of the perspectives and practices of these teachers.

\section{Context and Participant Selection}

The study took place at Treitman Shores (pseudonym), a low-income (85\% free/reduced lunch) K-5 urban elementary school with approximately 820 students. Racial demographics comprised of $51 \%$ Hispanic, $38 \%$ black, $8 \%$ white, and $3 \%$ Asian students. A total of 51 out-ofschool suspensions were reported during the first two months of school. Review of discipline data for the academic year demonstrated a persistent racial discipline gap. In fact, $61 \%$ of students suspended were black and males made up $66 \%$ of the total suspended population. The school handbook highlights zero tolerance for misbehavior and explicit rules are outlined for detention procedures. As an example, "talking, working, or eating during the detention is not allowed. Water and/or bathroom breaks are not permitted... This is a punishment, not a social time." As a whole, the discipline at Treitman Shores is haphazard at best, with no school-wide system for working with students' behavior. Some teachers sent students to the office on a daily basis, and some never at all. During the study, I observed the same students sitting in a small back room in the office because their teachers removed them from the classroom.

An exemplary teacher in this study is defined as one who has been nominated by the school's principal as obtaining repeated measures of high academic student performance, holding high expectations of students, and demonstrating successful approaches to working with student behavior. I asked the principal to consider teachers who: a) rarely, if ever, refer students to the 


\section{RESISTING PUNITIVE SCHOOL DISCIPLINE}

office, b) teach in similar grade levels, and c) teach in a general education, diverse classroom. Diverse in this context means the students represent various racial, cultural, and socioecomonic backgrounds consistent with the larger demographics of the school. Two fifth-grade teachers, Ms. Geller and Ms. Pearl (pseudonyms), were nominated and agreed to participate. Both teachers have only taught in low-income, urban areas in this school district.

Ms. Geller, a white teacher in her early thirties was working on her doctoral degree in education and has been teaching for nine years. She grew up in a middle-class suburban community just outside of the school district with five siblings, and recalls respect for one's elders as a significant part of her upbringing. Ms. Pearl is a black teacher beginning her nineteenth year of teaching. A native of the area, she came from a working-class family of seven siblings. In her interviews, she talked openly about race-based assumptions and stereotypes her family encounters as people of color. For instance, she shared that she has been accused of acting white because she speaks the dominant US dialect.

\section{Data Collection}

Data collection included formal and informal interviews, and observations. Each teacher was formally interviewed three times and followed Hatch's (2002) "flexible structure;" that is, the interviews went in the direction that the teacher took them, and drew on the teachers' unique experiences. The appendix provides a few sample questions I asked the teachers. On average, their interviews lasted 62 minutes and were transcribed. Also, archival data such as the school's handbook and discipline data contextualized the study.

Direct, frequent observation (Spradley, 1980) in the classroom allowed me to find patterns in the teachers' behavior and prompted me to ask specific questions in the interviews 


\section{RESISTING PUNITIVE SCHOOL DISCIPLINE}

about their practice. To understand the teachers' experiences at school, I conducted context observations (Angrosino \& Mays de Perez, 2000) and attended other school-related activities outside the classroom, such as following them to the library, cafeteria, and assemblies. My ethnographic observations began with a broad focus and later narrowed as I grasped a better understanding of the context. Spradley (1980) describes these first explorations into research settings as "grand tour observations" (p. 77), an initial approach that pays attention to the major features of the social context rather than the specifics. In the beginning, dimensions such as explicit understandings of classroom culture, expectations, and teacher language when responding to students' behavior, were observed and recorded using field notes. My prolonged engagement enabled my observations to be more focused, and led to asking informal interview questions that followed up on the decisions specific to each teacher's practice. Ms. Geller and Ms. Pearl were observed 14 times each for about two hours per visit. Field notes taken from the observations guided conversations about specific events during the interviews.

When possible, informal interviews occurred directly after observations to get immediate feedback, interpretation, and clarification about observations on that particular day. For example, in an observation in Ms. Geller's classroom, I overheard parts of a private conversation with her and a student in what seemed to suggest that the student was being disrespectful. After that observation, I asked her, "Can you tell me more about the conversation you had with Rashawn earlier? I overheard you use the word disrespectful and you asked him to stop rolling his eyes." During the study, Ms. Geller was asked 10 informal interview questions and Ms. Pearl nine.

\section{Data Analysis}

Social-construction research fits well with constructivist grounded theory analysis, as 


\section{RESISTING PUNITIVE SCHOOL DISCIPLINE}

both underscore the importance of shared experiences between the researcher and the participant (Charmaz, 2006). First, I read all interviews and field notes to determine initial codes for each teacher and coded meaning units as gerunds whenever possible to refrain from making conceptual leaps. Initial coding guided decisions about future core conceptual categories from which the analysis was constructed. Constant comparative methods determined analytic distinctions throughout the analysis process. As an example, I compared the daily routines that the teachers used to maintain the classroom environment across all field notes.

Then, I separated, sorted, and synthesized initial codes to form broader conceptual categories, or focused codes for each teacher. For example, the initial codes "using terms of endearment," "engaging in personal conversations," and "fixing students' special chair," indicated ways that Ms. Geller communicated care for her students. These initial codes were subsumed under the larger focused code "demonstrating care." As focused codes emerged, memo writing helped to define and characterize larger categories for further analysis. Through this recursive process, I sought confirming and disconfirming evidence in the data. For example, in an initial visit to Ms. Pearl's classroom, I perceived her to be yelling at students but in an informal interview, she clarified that this was not the case. Rather, she was communicating energetically and one of the ways she accomplished this was by projecting her voice loudly. As observations continued, it became apparent that students did not perceive Ms. Pearl to be yelling at them, as they were engaged during instruction, confided in her, and appeared comfortable.

\section{Trustworthiness and Researcher Positionality}

The goal of trustworthiness is to support the argument that a study's findings are "worth paying attention to" (Lincoln \& Guba, 1985, p. 290). I triangulated the data to ensure that 


\section{RESISTING PUNITIVE SCHOOL DISCIPLINE}

conclusions were drawn from a cross-examination of the interviews, observations, and field notes. I sent each teacher her case and conducted a final member checking interview which provided the opportunity to verify, clarify, or add to the findings represented in their case. In response to her case, Ms. Geller said:

It was really quite fun to relive those moments with the kids (a few made me $\mathrm{LOL}^{1}$ )...I must say that it made me feel proud of the work I do... you summarized succinctly how I see myself as an educator and what I find to be the most important elements of my work. Using a researcher journal for reflexivity provided the opportunity to continually record and reflect on assumptions of the data as they emerged.

My research interests lie in pursuing questions related to equity and eradicating injustice in the context of low-income, urban schools. I strive to work toward anti-oppressive research, which argues that research (and anything for that matter) is never neutral (Kumashiro, 2009). I am a former elementary school teacher in the US and in Japan and have worked with students from various backgrounds. My commitment to improving equity and excellence in schools motivates me to stay connected to schools and teaching. As I write this paper, I recognize that this endeavor is much more than publishing and presenting this work. This study is about highlighting the teachers' multifaceted perspectives and practices related to their teaching and their larger mission for the children and community they serve.

\section{Findings}

Despite my attempts to elicit Ms. Geller and Ms. Pearl's thoughts directly related to student behavior (e.g. "Whose behavior do you find challenging?"), both teachers repeatedly

${ }^{1} \mathrm{LOL}$ is an acronym for "laugh out loud" in Internet slang. It is commonly used in computermediated communication. 


\section{RESISTING PUNITIVE SCHOOL DISCIPLINE}

redirected the interviews and spoke more broadly about all of the skills they needed to teach students. The cases do not highlight the stories of teachers who believe that some students are "bad" or "troublemakers" who need to be fixed. Mrs. Geller and Mrs. Pearl believed in teaching the whole child; that is, they were concerned about students' safety, physical and emotional wellbeing, and character, as well as their academic development. In what follows, we learn about the perspectives and practices of exemplary urban elementary teachers who refuse to rely on punitive discipline with their students of color.

\section{Ms. Geller: Learning for Life}

The center of Ms. Geller's teaching stance is what I have come to call "learning for life." At the core, she was deeply focused on preparing students for successful lives and believed it was her responsibility to actualize that success. Ms. Geller repeatedly referred to "student learning" as the overarching goal for students and insisted it was her responsibility to ensure that students were successful. She expressed this goal in her interactions with students:

Ms. Geller: What's this benchmark test? Give me a hand in the air if you know. [a few students raise their hands]

Ms. Geller: The benchmark test is just to see what you know. I do expect you to do well at the end if I've done my job, right? I'm confident that you'll do well so don't give up just because it gets a little annoying.

From her perspective, student learning went far beyond mastering academic skills; it also included learning life skills so that students would experience success within and outside the classroom walls. She believed learning went far beyond materials in the textbook and explained that teaching students how to stay organized or how to respond in challenging situations such as 


\section{RESISTING PUNITIVE SCHOOL DISCIPLINE}

inquiring about an erroneous fee at a bank were just as crucial as academic skills.

Ms. Geller kept track of their achievements and understood student differences. In our interviews, she expressed that students had different strengths and skills they needed to improve, but one thing was clear - these differences did not reflect a student's innate ability to learn. Even students who frequently got in trouble by other teachers and administrators were not viewed from a deficit perspective. Referring to one of her black students who garnered a school-wide reputation for problematic behavior, Ms. Geller said:

I like him. He takes more redirecting than some of the other kids. ... He likes to sing; everything I say turns into a song, but I don't interpret that as bad, just lively. [laughter] I really think that he's so smart; he's got a lot going on in his head, and it's just impulsive. ... Like today, I said something about no excuses, and it was like, 'no excuses, no promises,' whatever that song is, and he starts singing. I was like, 'Right, no excuses, promises, whatever... get to work.'

Rather than view his behavior as a supposed deficiency, Mrs. Geller chose to view this student's singing from an asset-based perspective. Drawing on this student's cultural wealth (Yosso, 2005), she was able to notice that "he's so smart; he's got a lot going on in his head." There were no excuses for failure, because she genuinely believed that success was within her students' reach.

It was no surprise to hear Ms. Geller talk about the purpose of school: "I believe the function of schools is to develop thinkers and doers, facilitate individuality and creativity, and promote the desire for students to be strong contributors to our society." She viewed herself as the conduit between her students and their learning, and talked about her role in preparing 
RESISTING PUNITIVE SCHOOL DISCIPLINE

students to contribute to society:

I want my role as a teacher to be to foster an environment where I am pushing them to think in different ways, challenge scenarios, provide strong reasoning for their beliefs and thoughts, communicate their thinking accurately, and transition creative ways of thinking into some type of action.

Getting students to think differently and to challenge scenarios are indications that she wanted to prepare students to take action toward improving society. Focused on nurturing the whole child rather than an agenda that merely addressed academics, three principles of practice guided how Ms. Geller enacted learning for life.

Principles of Ms. Geller's Practice

Three principles guided her practice: 1) knowing students and caring for them, 2) assisting students to achieve high expectations, and 3) empowering students as collaborators in teaching and learning. Although I separate them for purposes of description, these principles are interrelated in practice.

Knowing students and caring for them. Building relationships and communicating care were a priority for Ms. Geller. She made the connection between knowing students and showing her care clear:

The first two weeks of school, while everybody's already into the curriculum, I'm like the curriculum's going to wait. I don't do what the pacing guide says to be doing the first two weeks of school; I don't even touch it. I just focus on [relationships]. Because I think that building relationships in the beginning and getting to know them and making them think that I care is more important than jumping into focusing on [the] curriculum. 


\section{RESISTING PUNITIVE SCHOOL DISCIPLINE}

Delving into the curriculum would eventually come, but helping students feel understood, accepted, and connected to her and their peers conveyed her care for them. Ms. Geller communicated her care through getting-to-know-you activities and differentiating her teaching.

On the first day of school, students completed questionnaires that elicited a range of responses about their interests, strengths, and experiences. She then spent the next two weeks conducting mini-interviews with each student, getting to know them on a more intimate level. It was in these interviews where she was able to dig deeper, learning about their family life and how they perceived themselves as students. By understanding the contextual layers that shaped students' lives, she was able to help them in learning for life. Ms. Geller was adamant about finding ways to reach students. To do so, she had to know them on a personal level:

They need that personal level. I need to know who their families are, I need to know what they like, where they come from, what their struggles are, why, why are they struggling, what helps them, all of those little things. It's my responsibility ... that I use those to help them with the goal of student learning.

Ms. Geller also enabled students to get to know her because she believed that reciprocity in the relationship was key for students to perceive her care. In the following example, Ms. Geller showed her personal side when talking about her unborn baby:

Student: Oooh, you are going to the doctor today to find out if it's a girl or boy inside of your belly!

Mrs. Geller: Yes! You're right! (students are excited and make guesses under their breath) Let's take an official poll now and then when I get back from the doctor tomorrow, I'll tell you what it is. So, who thinks it's going to be a girl? (16 students raise 
RESISTING PUNITIVE SCHOOL DISCIPLINE

their hands) Who thinks it'll be a boy? (five students raise their hands) So, if we made that into a pie chart, it would look like this (She draws a pie chart on the board representing students' predictions using a red marker for girl and a blue marker for boy). Well, you'll find out tomorrow!

Allowing students into her personal life humanized her and made them feel comfortable.

Ms. Geller also explained the significance of knowing students as a means to differentiate her instructional practices:

That's where you have to know your students. ... I may have to for one student only one time, go over and put my hand on their shoulder or look at them a certain way, and they'll respond that one time and it will be fixed. There's other students that I could do that fifty times and that's just not going to work.

Interviews revealed Ms. Geller's deep knowledge of each student made her cognizant of the different learning each student needed to work on. Some of these included handwriting skills, organization skills, staying on task, setting personal goals, and having a positive attitude.

Observations supported interviews where she described her different approaches to assisting each student's transformation. For example, Ms. Geller used a special hand code for a student who constantly called out during instruction. This particular student craved attention; therefore her subtle, special hand code made him feel as though he received special attention. Taking the time to communicate with a non-verbal hand gesture was an effective reminder for the student without embarrassing him or making it appear to other students as though he received special treatment.

Ms. Geller used her knowledge of families' communication styles to interact with 
RESISTING PUNITIVE SCHOOL DISCIPLINE

students in differentiated, culturally responsive ways. She described how she conveyed the same message in contrasting ways:

I have one student that is very soft-spoken and when I've met with his parents they're both very soft-spoken people...when they talk to him they're, 'You understand honey?' and they're very sweet and I know that if I were to ever raise my voice it would probably freak him out; he would probably crawl into his shell and that would be it. So he's somebody that I have to reflect what I see he's used to at home, and so even if he's done something that I would normally be upset and say, 'We need to talk about this' and maybe become a little bit more stern, with him I have to say, 'Do you understand what I'm saying?' I have to come across that way and I see that he responds really well to that. And then there's other students that if I try to have a conversation with them like that, they've zoned out; they couldn't care less. I really need to get them to look me in the eyes, and I need to come on with a stern voice in order for them to be like, 'Oh, she means business; I better listen. I need to get my act together.'

Addressing a soft-spoken student in a stern and direct manner could have led to feelings of intimidation and disengagement whereas a stern and direct style was likely to be effective with other students.

Assisting students to achieve high expectations. As a teacher who refused to accept anything less than students' best, Ms. Geller was consistent, reminded students of her expectations, and expressed the importance of being consistent as a means to bolster their success. She viewed her practice as a careful balance between supporting and pushing students to reach her expectations, and she was able to push students to achieve because of the caring 
RESISTING PUNITIVE SCHOOL DISCIPLINE

relationships she had worked to cultivate. She stated, "Because of the background and because of the foundation that I've built with them, I have these conversations and I try and teach them and lead them there. Then, once I know they know better, I push them.” From her perspective, she could not simply demand what she expected from them; she had to assist, or show them how to reach success. For example, making inferences in different texts was a skill that was continually practiced from the beginning of the year. Therefore, when a student rushed to finish his reading assignment, she firmly said, "No, your inference does not have SPECIFIC evidence. You must be specific and draw conclusions from the text." Returning his paper, she insisted "Remember, how do you know? You have to prove it."

Other observations corroborated the importance of assisting students in meeting high expectations outside of the academic curriculum:

Ms. Geller: Is that organized?

Student: No.

Ms. Geller: How could this be more organized? [She tells the student to get his folder.]

Part of not being organized is not putting things in a specific place. [She places his homework in the left-side pocket of his folder.] Next time you need to put your homework in your folder. It's gonna take work for you to remember this but you need to do it to stay organized. Next time we take out homework, I'm going to be looking at you to make sure you take it out of your folder.

Student: [nods his head] Yes, Ms. Geller.

She demanded that the student stay organized not only because he often misplaced his homework assignments, which was detrimental to his academic success, but staying organized 
RESISTING PUNITIVE SCHOOL DISCIPLINE

was a skill she believed was necessary for success in life. Unwavering in her efforts, she supported the student by showing him how to be more responsible. Then, she pushed him by clearly asserting her expectation ("Next time you need to put your homework in your folder."), and told him that she would hold him accountable ("Next time we take out homework, I'm going to be looking at you to make sure you take it out of your folder."). She exercised authority and monitored students because she took responsibility for student learning.

\section{Empowering students as collaborators in teaching and learning. Ms. Geller}

empowered students by co-creating classroom rules and helping them to establish and meet personal goals. On the first day of school, she facilitated a discussion to provide students the opportunity to voice their ideas for the kind of learning community they desired. Ms. Geller believed that students were more likely to comply when rules were generated by the students themselves. She genuinely valued student input and empowered students by using their ideas in her instructional decisions. When a student proposed a change in a reading assignment, Ms. Geller said, "Yes, that's a good idea," and encouraged other students to make this change if it helped them. As students came to the end of reading Holes, a classmate suggested that their next novel be Small Steps, the sequel to Holes. Recognizing their excitement about this prospect, she promised to investigate the book.

Another aspect of empowering students as collaborators was establishing and meeting student-created goals. These were referred to as "action plans" and involved intentional planning to improve individual student goals. The following is a conversation between Ms. Geller and the aforementioned student who needed assistance with staying organized:

Ms. Geller: What do I expect when you don't have your assignment? Where is your 
RESISTING PUNITIVE SCHOOL DISCIPLINE

homework assignment? Take out your homework folder.

[Student takes out his homework folder, but there is no homework assignment.]

Ms. Geller: Wait, what did we agree? It wasn't my rule, WE agreed on it. Listen to me.

You put it in there last night and it disappeared? No, that's not believable. Listen to me.

I'm disappointed because I was excited to come in here this morning and see you take out your homework from that folder. Okay, we need to try this again tomorrow.

[Minutes later, the student continues to dig in his backpack and finally finds his

homework assignment crumbled with other miscellaneous papers. He immediately brings it to her.]

Ms. Geller: And where was it? Why was it there? You need to promise me that tomorrow, you will have your homework in your folder.

Student: I promise, Ms. Geller.

In my next observation, Ms. Geller asked students to take out their homework to review. Open on the student's desk was his folder, with his homework assignment inside of the left pocket. With a sense of pride, he smiled and sat up straight, ready for her to check his assignment. The practices of Ms. Geller-knowing students and caring for them, assisting students to reach high expectations, and empowering students as collaborators in teaching and learning - point to her unwavering commitment to coaching her students of color to experience successful lives full of possibility.

\section{Ms. Pearl: Learning for Liberation}

Ms. Pearl's teaching was deliberately concerned with preparing students for liberation-- a term that emerged in my analysis of the data. Similarly to Ms. Geller, Ms. Pearl wanted students 


\section{RESISTING PUNITIVE SCHOOL DISCIPLINE}

to experience success and believed it was her responsibility to help them to accomplish that success. Her understanding of students' sociopolitical realities compelled her to teach for the purposes of transforming students' lives. This was clearly evident in her first interview:

As a teacher, my job is to empower, and I feel great... I'm only as good as my students. I may be a good teacher but you know what, if [they] don't get it, I have failed. I have done something wrong. I have failed [the students], I have failed myself, so if something is wrong, we need to correct that, we need to fix that.

She believed that teachers had to prepare students beyond "teach[ing] just the ABC's," and explained that students had to learn many skills including respect, compassion, empathy, and acceptance of others. Focusing narrowly on academics would impair them in becoming wellrounded adults:

When I give my kids lifelong lessons, that's important to me because when they leave this classroom, when they leave middle school, you want to know that you prepared them to be productive citizens, respectful citizens ... that's important.

Her teaching approach was grounded in a social reconstructionist stance toward education, one based on the perspective that social systems are unjust and in need of change. In this role, the teacher prepares students to "take charge of their lives, work collectively with others, and speak out" (Grant \& Gomez, 1996, p. 10). Working toward social reconstruction, Ms. Pearl's ultimate aim was for students to become leaders that determined their own path:

I've opened the window for my students to just soar because they have the confidence inside of them that they feel, 'I can do anything that I want to do. I determine the path that I go though.' I'm empowering them to be effective leaders, not only inside but 
RESISTING PUNITIVE SCHOOL DISCIPLINE

outside the classroom.

According to Ms. Pearl, students did not view themselves as successful because of their past schooling histories. Therefore, she believed it was her duty to help students rethink what they were capable of:

When I see a kid at the beginning of the year, [their] whole mindset has been transformed. ... When I see the transformation of my students, that is when I know my work is done. At the end of the day I look at Marisol, ESOL student. Teachers have said, 'Well, she didn't do anything last year.' I said, 'Really? She's performing for me. She's doing exceptionally well.' When kids know you genuinely care... you could take them to a totally different level, and that's what I do.

Ms. Pearl worked to undo the deficit labels by helping students see themselves in new waysfrom silent to confident, from timid to bold, and from low-performing to capable.

Mrs. Pearl was keenly aware of students' struggles and anticipated future opposition they would face as people of color. As a woman of color, this was her lived experience. She described acquaintances telling her that she is not really black because she seems so educated and stories about her own children being misunderstood. She shared, "A lot of black boys are misunderstood. Sometimes teachers don't know how to tap into their interests and I can say that because I have a black son who is misunderstood." Ms. Pearl acknowledged the dominant narrative of people of color as deficient. Therefore, she was determined to teach in ways that would help students break free from society's chains that restricted their access to successful lives.

\section{Principles of Ms. Pearl's Practice}


RESISTING PUNITIVE SCHOOL DISCIPLINE

Ms. Pearl accomplished learning for liberation through her enactment of three main principles of practice: 1) othermothering, 2) facilitating student engagement, and 3) insisting on high expectations.

Othermothering. Consistent with the literature on successful black teachers, Ms. Pearl viewed herself as an othermother, expressing her maternal care and commitment to the psychoeducational needs of children she declared her love for: "You have to have somebody showing them the direction, showing them the correct path to go down and that is what I do as a teacher, as a mother. I'm like a mother to these kids, a second mother." As their othermother, she viewed it as her responsibility to shepherd students down the path of success. Ms. Pearl used several strategies to express her othermothering which included establishing a close bond with students, providing comfort, and uplifting the community.

She established an interpersonal bond with students and even though they were not her biological children she expressed, "I care for each and every one of them the same way I care for my own children. The same way I treat my son and my daughter, I treat them the same exact way." For instance, when a student felt ill just before winter break, she comforted him yet told him he needed to continue with the task at hand:

Ms. Pearl: Come on baby Jordan, you don't feel well? Does your head hurt? (puts her hand on his shoulder)

Ms. Pearl: Ms. Pearl wants you to feel better. Did you eat? (Jordan nods his head.) Jordan, you are doing so well and Ms. Pearl needs you to keep up that momentum. Don't give up now. Give me ALLLLL you, what?

Jordan: GOT! 


\section{RESISTING PUNITIVE SCHOOL DISCIPLINE}

From Ms. Pearl's perspective, feeling psychologically safe in the classroom was critical for learning to take place. Establishing this kind of environment reinforced her larger mission of learning for liberation. She said,

If I provide that comfortable environment for you and you feel it's okay to share this, it's okay to say this, eventually it's going to be instilled in you that it's okay to have that voice, regardless of what your home situation might be like, regardless if your parents are working two or three jobs.

Explicit in her desire to alter their life trajectories, students had to learn in conditions that made them feel safe. Ms. Pearl worked to achieve a comfortable learning environment by creating a community that acknowledged others' progress (clapping for a job well done, “Oh Ms. P., she's reading more fluently!"), immediately redirecting students that attempted to compromise the comfortable environment ("Shut up is such a negative word. Why don't you try that again?"), using terms of endearment in her discourse ("sweetheart," "Hey baby, how you doin'? We're glad you're here"), and using humor in her interactions with students ("This is wacky, wacky Ms. Pearl's class, okay?"). In the middle of the year, she welcomed a new student from Mexico who appeared timid upon entering a new classroom. To cultivate a comfortable environment, Ms. Pearl asked each student to introduce themselves. Making the student feel welcome, many students took her request one step further and introduced themselves in Spanish to make him feel comfortable in his new environment. Even students did not speak much Spanish attempted to introduce themselves in Spanish, going out of their way to make the new student feel accepted. Students were excited to have a new member in their community, giving high-fives and shaking his hand as they introduced themselves. 
RESISTING PUNITIVE SCHOOL DISCIPLINE

Her enactment of othermothering also included her commitment to uplifting the larger community. She asserted, "Your parents had to struggle to get here, your parents have to struggle to maintain. ...I don't care if your parents don't know how to read. You read to your parents. That's what you're going to do." In other words, one of the aims of learning for liberation was to empower students' family members who struggled to live prosperous lives. Her classroom was a site for social activism - she expected students to use what they learned in school to then educate their family members at home. As an othermother, she encouraged students to teach their families new words, how to navigate different computer programs, and how to read. As their othermother, Ms. Pearl saw education as a means of liberation.

Facilitating student engagement. Ms. Pearl's students exhibited enthusiasm, effort, and concentration as she worked toward learning for liberation. Her instruction aimed to get students excited about instructional content to engender a love for learning. A primary way she achieved this was through storytelling which she believed helped her to relate to students in a personal manner. She explained,

They relate to the stories I tell them ... I bring in a personal side of me. When I bring in that personal side of my through storytelling, it makes it much easier for my kids to understand and then perform for me ... wanting to do their very best.

Some of the stories were about her family. For instance, when she explained the word "recede," she connected the word to her husband, Dr. Pearl. "You see, Dr. Pearl is getting old and he has a receding hairline now." She shared stories about the challenges her children face because they are black, including her son's experiences of being called derogatory names as the only black player on his high school baseball team. In addition to Ms. Pearl's stories, her students readily 


\section{RESISTING PUNITIVE SCHOOL DISCIPLINE}

talked about important issues that concerned them in their own lives. This next example shows

Ms. Pearl facilitating an incident that arose about racism:

Student: There's a little boy in my neighborhood who doesn't like them.

Ms. Pearl: Who is them? You mean black people?

Student: (nods her head) He says they smell and look like ca-ca.

Student: Yeah, he's racist.

Ms. Pearl: I think you're right... That could be something that is a LEARNED behavior.

Let me ask you, if there was something you could all say to him, what would you say?

Student: I would say, 'You need to respect other people.'

Student: That's not right.

Student: Everyone is human.

The rest of the discussion was facilitated by Ms. Pearl about how students could respond if and when they were in a similar situation. In an era of colorblindness, Ms. Pearl facilitated student engagement by following their lead and discussing salient issues the students wanted to discuss.

Another way she facilitated student engagement was by teaching with intensity. Ms.

Pearl's words best describe the intensity that was a prominent feature of her character:

My kids will say to me, 'Well, Ms. P., you're just different. I just love you, I just love the way you teach, the way you scream, and you just get into it, and I just love it. I love it when you say, 'love it!' It's the energy, and that pours over to my students and it makes a big difference.

Teaching with intensity included her energy, the boisterousness, and constantly moving around the room. She revealed, "It's like I'm on stage. I'm an actress and I just love it. ... I transform." 


\section{RESISTING PUNITIVE SCHOOL DISCIPLINE}

In other words, her "stage presence" and entire delivery helped to captivate her students. Loud and at times a bit dramatic, her spirit was infectious. The following remarks highlight the intensity that permeated the classroom:

Ms. Pearl: How are you guys today?

Students: [in unison] FABULOUS!

Ms. Pearl: Oh, I am so glad you're FABULOUS!

Ms. Pearl described herself as boisterous, and she instructed with emotion that allured the students, making learning more enjoyable. When students worked hard she often exclaimed, "Y'all are on fire! Keep it up," as a way to encourage student engagement.

Insisting on high expectations. Ms. Pearl believed that having high expectations pushed students to reach for excellence. She asserted, "I have high expectations ... I always knew that if you took kids, if you exposed students to another level, they would perform for you." She wanted students to experience success and therefore, expected that they always try their best. On several occasions, she told students that they needed to be able to use the very skills she taught them when (not if) they went to college: "When you go to college, I want this to be second nature to you. I want you to be able to examine, judge, process and I'm going to provide you with the tools to do that."

During individual presentations, she expected students to speak clearly and confidently. When a student began to mumble about his project, she stopped him and said, "WAIT, WAIT. You are not mumbling to us. You need to open your mouth and speak." Dissatisfied with the student's low volume, she demanded that he start from the beginning. By insisting that he start over, she insisted the student meet her expectations, which reinforced her message that he was 
RESISTING PUNITIVE SCHOOL DISCIPLINE

capable of success.

Just as she expected them to be clear in their speech, Ms. Pearl was explicit in communicating her expectations. She asserted, "You are fifth-grade students. The quality of work I expect of you is one in which you have to do research, present, and speak in front of the class. Remember we talked about expectations?" Requiring students to think critically, the following observation illustrates how she used a call-and-response strategy to remind them of her expectations before they began a task:

Ms. Pearl: I tell you to think. I tell you to analyze it. WHY DO YOU ANALYZE THE QUESTION?

[One student answers.]

Ms. Pearl: What else do I want you to do? You have to do WHAT?

Student: INTERPRET!

Ms. Pearl: You have to interpret! Very good sweetheart. What else do I want you to do sweetheart? Are you going to underline every word in that question?

Students: [in unison] NO!

Students' synchronized responses show that this was a common strategy Ms. Pearl used to reinforce her expectations.

\section{Discussion and Implications}

For over 40 years, school discipline policies and practices have pushed children out of schools and into the juvenile and criminal justice systems. Educators remove over 3.45 million students each year for punitive disciplinary reasons, the majority of whom are of color, albeit consistent findings that demonstrate its harmful effects (U.S. Department of Education Office for 


\section{RESISTING PUNITIVE SCHOOL DISCIPLINE}

Civil Rights, 2014). This paper contributes to our knowledge about educators who support urban youth and who reject dominant deficit ideologies related to student behavior. The study provides insights into the perspectives and practices of exemplary teachers who actively teach against the grain in a school environment that relies on punitive discipline. Examining exemplary teachers' views about behavior and connecting those views to their practice is important in helping educators disrupt the beginning of the STPP. Believing that academic learning is merely one of the many dimensions that define success, the teachers refused to give students what LadsonBillings (2002) calls "permission to fail" (p. 108) That is, these are teachers who help students flourish, refusing to pity them by lowering their expectations.

Of significance is Ms. Geller and Ms. Pearl's larger goal of improving students' lives, not fixing their behavior. I argue that this very ideological stance is what makes them exceptional. Rather than partition the academic and social curriculum, they expected all students to need help learning a variety of skills, and they embraced their role to nurture the development of the whole child. While educators often repeat the mantra "all students can succeed," some attach qualifiers to this belief, suggesting that there are limits to what teachers can accomplish. It is not uncommon to hear statements such as, "All students could succeed if they weren't so lazy" or "All students could succeed if their parents value education," placing blame for student failure on students' families or other variables unrelated to teacher and school practices. At the heart of Ms. Geller and Ms. Pearl's practice is what Corbett, Wilson, and Williams (2002) call an "it's my job" approach, which insists that students can, will, and must succeed - and the teacher assumes responsibility in ensuring student success.

The findings also support the importance of the teachers' demonstrations of critical care 


\section{RESISTING PUNITIVE SCHOOL DISCIPLINE}

for their students. Ms. Geller's role was that of a life coach — teaching students how to respond in challenging situations, perseverance, and learning how to work with others. She believed it was her responsibility to support and push students to meet her high expectations; that is, she had to show students how to reach success. Ms. Geller's role as life coach echoes Ladson-Billings' (1994) sentiment regarding effective teachers of urban students: "Effective urban teachers play the role of 'conductors' or 'coaches' who assume responsibility for their students' academic development rather than playing the role of 'custodians' who merely watch over students" (p. 23). Roberts (2010) highlights significance of teacher political clarity as a crucial component of the CRCTC framework. Bartolomé (2009) explains that "a number of possibilities exist for preparing students to deal with the greater society's unfairness and inequality that range from engaging in explicit discussions ... to more indirect ways (that nevertheless require a teacher to be politically clear)" (p. 342). Because of her students' marginalized status, Ms. Geller understood that her students of color must perceive teachers' language and actions as care. This view dispels the dominant narrative that caring actions are universal. In fact, her desire for students to challenge scenarios and engage in praxis were ways that she enacted critical care for students.

As a white teacher, Mrs. Geller's commitment to viewing students from an asset-based perspective was absent in her early teaching. In a previous article that extends this paper (Author, 2016a), I share how Ms. Geller spoke openly about how she once pitied and made assumptions about her students: "[I] assumed poor them, this is what they need... I never stopped to ask the students, 'What are some things that a teacher's said to you or done in the classroom that's really been so helpful? What hurts you?" She revealed that she "was very much a dictator... in control 


\section{RESISTING PUNITIVE SCHOOL DISCIPLINE}

of everyone's behavior by silencing them." Steeped in whiteness, Ms. Geller was once unaware of the role played by socialization in influencing her beliefs, values, and ways of being. This is not surprising given that people in dominant positions often believe that their knowledge is universally shared. However, continued coursework through an education master's degree led her to challenge her taken-for-granted assumptions and critically examine her interactions with students. The story of Mrs. Geller points to the possibility of shifts in thinking and practice with a deep commitment to "always evolving, always encountering new ways to irritate dominant forms of power" (Kincheloe \& McLaren, 2013, p. 407).

Committed to helping students navigate a racist society, Ms. Pearl explicitly prepared them to take on the unavoidable challenges that lay ahead. Ms. Pearl's political clarity recognized the sociopolitical realities of her students, and her lived experience as a black mother raising two black children in a middle-class community engendered an emancipatory lens that guided her teaching. She worked to uplift students' families, taught students to embrace others, and helped them to respond in oppressive situations. Mrs. Pearl's liberatory pedagogy sought to be a transgression of and preparation for destroying the chains that keep her students imprisoned to the unconditional acceptance of their oppressive conditions (hooks, 1994). To be clear, this study does not suggest that this is the type of education that students from marginalized backgrounds must have. What the study does suggest is that their principles of practice may be useful for teaching and reaching students of color because of opportunity gaps steeped in racial inequity across the globe.

In addition, the study reveals that educators may work more effectively with their students of color if they reframe deficit and punitive views of student discipline. The study 


\section{RESISTING PUNITIVE SCHOOL DISCIPLINE}

shows that Ms. Geller and Ms. Pearl refused to label their students as deficient or bad, nor did they rely on a deficit discourse that sees deprivation in communities of color. Indeed, the teachers challenged deficit ideologies (Valencia, 2010; Weiner, 2006) about students' aptitudes, unlocking the cultural wealth in their community by gaining awareness of student and family assets, and viewing families as partners in student success (Yosso, 2005).

The atrocious inequities in school discipline policies and practices have led the US Departments of Justice and Education (2014) to provide guidance to school districts in helping schools change current practices. The findings of this study contribute to a growing body of research that further supports $\mathrm{CRCM}$ as an orientation to teaching that helps teachers create culturally responsive caring environments to bolster student learning. This study adds to the literature by connecting the teachers' stances to their pedagogical practices that aim to create classroom environments that support students' academic and socio-emotional learning. Culturally responsive classroom managers understand the role of culture in student behavior and use preventative, not reactive practices in classroom management (Skiba, Ormiston, Martinez, \& Cummings, 2016). While strategies are one aspect of teaching, often overlooked in the literature is the role of educator beliefs in changing school practices (Giroux, 1988). Teachers and teacher education programs who disregard the importance of educator beliefs to focus merely on strategies are no threat to dismantling inequity. If we hope that teachers are to become politically clear, it is crucial that teachers and teacher educators commit themselves to (un)learning deficit ideology and shifts in consciousness (Author, 2016b).

Education stakeholders may want to scrutinize their tacit assumptions about their students of color. Teachers and teacher educators who become vigilant about their own blind spots are 
better able to dismantle deficit thinking and work to provide equitable opportunities for the students they serve. The study helps both researchers and practitioners reflect on the concept that discipline assumes as well as illustrate what CRCTC may look like in practice. Future research efforts may also want to address student views about discipline in relation to race, gender, and socioeconomic status. To conclude, the study demonstrates the teachers' unwavering commitment to improving students' lives, confirms the practices of CRCM, and expands upon a culturally relevant kind of teacher care for children of color. In Ms. Geller and Ms. Pearl, researchers and practitioners have models of the beliefs and practices central to eradicating racism that fuels the school-to-prison-pipeline. 


\section{Appendix}

Sample Interview Questions

1. Tell me about the relationship you have with your students. Are some relationships easier to cultivate than others? Why do you think this may be?

2. As you know, you were nominated as a teacher who is effective with student behavior. What are your thoughts about this? Why do you think your principal nominated you?

3. What expectations do you have for classroom behavior and responsibility? How do you communicate those expectations to students?

4. Do you think about student behavior now in the same way as you did when you first began to teach? What is the same? What is different? Why has your thinking changed?

5. Whose behavior are you concerned about? What concerns you? What do you think you might do about it?

6. I notice that you frequently (name a practice observed repeatedly). Tell me more about this.

7. I notice that (student's name) frequently (describe what student does/says). What do you make of this? Are there things you need to do to follow up on this? 


\section{References}

Acosta, M. M. (2015). “No time for messin' around!” Understanding Black educator urgency: Implications for the preparation of urban educators. Urban Education, doi: $10.1177 / 0042085915613545$.

Alexander, K., Entwisle, D., \& Kabbani, N. (2001). The dropout process in life course perspective: Early risk factors at home and school, Teachers College Record, 103(5), 760822.

Author (2007).

Author (2016a).

Author (2016b).

Bartolomé, L. (2009). Beyond the methods fetish: Toward a humanizing pedagogy. In A. Darder, M. P. Baltodano, \& R. D. Torres (Eds). The critical pedagogy reader (2nd ed.) (pp. 338355). New York: Routledge.

Beauboeuf-LaFontant, T. (2005). Womanist lessons for reinventing teaching. Journal of Teacher Education, 56(5), 436-445.

Brophy, J. E. (1988). Educating teachers about managing classrooms and students. Teaching and Teacher Education 4(1), 1-18.

Brown, D. F. (2003). Urban teachers' use of culturally responsive management strategies. Theory into Practice, 42(4), 277-282.

Brown, T. M., \& Rodríguez, L. F. (2009). School and the co-construction of dropout. International Journal of Qualitative Studies in Education, 22(2), 221-242. 


\section{RESISTING PUNITIVE SCHOOL DISCIPLINE}

Case, K. I. (1997). African American othermothering in the urban elementary school. The Urban Review, 29(1), 25-39.

Charmaz, K. (2006). Constructing grounded theory: A practical guide through qualitative analysis. Thousand Oaks, CA: Sage Publications.

Collins, K. M. (2011). Discursive positioning in a fifth-grade writing lesson: The making of a “bad, bad boy." Urban Education, 46(4), 741-785.

Collins, P. H. (1991). Black feminist thought: Knowledge, consciousness, and the politics of empowerment. New York: Routledge \& Keagan Paul.

Corbett, H. D., Wilson, B. L., \& Williams, B. (2002). Effort and excellence in urban classrooms: Expecting, and getting, success with all students. New York: Teachers College Press.

Crotty, M. (1998). The foundations of social research. London: Sage Publications.

Emmer, E. T., Evertson, C. M., \& Anderson, L. M. (1980). Effective classroom management at the beginning of the school year. The Elementary School Journal, 80, 219-231.

Ferguson, A. A. (2001). Bad boys: Public schools in the making of Black masculinity. Ann Arbor: University of Michigan Press.

Foster, M. (1998). Black teachers on teaching. The New Press.

Freire, P. (1993). Pedagogy of the oppressed. New York, NY: Continuum.

Giroux, H. A. (1988). Teachers as intellectuals: Toward a critical pedagogy of learning. Greenwood Publishing Group. 


\section{RESISTING PUNITIVE SCHOOL DISCIPLINE}

Goldring, R., Gray, L., and Bitterman, A. (2013). Characteristics of Public and Private Elementary and Secondary School Teachers in the United States: Results From the 201112 Schools and Staffing Survey (NCES 2013-314). U.S. Department of Education. Washington, DC: National Center for Education Statistics. Retrieved April 17, 2017 from http://nces.ed.gov/pubsearch.

Grant, C. E., \& Gomez, M. L. (1996). Making schooling multicultural. Englewood Cliffs, NJ: Prentice-Hall.

Gregory, A., Skiba, R. J. \& Noguera, P. A. (2010). The achievement gap and the discipline gap: Two sides of the same coin? Educational Researcher, 39(1), 59-68.

Gregory, A., \& Weinstein, R. S. (2008). The discipline gap and African Americans: Defiance or cooperation in the high school classroom. Journal of School Psychology, 46, 455-475.

Hatch, J. A., (2002). Doing qualitative research in education settings. Albany, NY: State University of New York Press.

hooks, b. (1994). Teaching to transgress: Education as the practice of freedom. New York: Routledge.

Kennedy-Lewis, B. L., Murphy, A. S., \& Grosland, T. J. (2014). Using narrative inquiry to understand persistently disciplined middle school students. International Journal of Qualitative Studies in Education, 29(1), 1-28.

Kincheloe, J. L. (2008). Critical pedagogy primer (2nd ed.). Peter Lang.

Kumashiro, K. (2009). Against common sense: Teaching and learning toward social justice. New York: Routledge. 
RESISTING PUNITIVE SCHOOL DISCIPLINE

Ladson-Billings, G. (1994). The dreamkeepers: Successful teachers of African American children. San Francisco: Jossey-Bass.

Ladson-Billings, G. (2002). I ain't writin' nuttin: Permissions to fail and demands to succeed in urban classrooms. In L. Delpit (Ed.), Skin that we speak: Thoughts on language and culture in the classroom (pp. 107-120). New York: The New Press.

Losen, D. J. (2014, June). Using the CRDC discipline data [Webinar]. Sponsored by Dignity in Schools Campaign. Retrieved from http://www.dignityinschools.org/document/usingcrdc-discipline-data-webinar-slides

Lincoln, Y. S., \& Guba, E. G. (1985). Naturalistic inquiry. Beverly Hills, CA: Sage Publications.

Kincheloe, J. L. \& McLaren, P. (2013). Rethinking critical theory and qualitative research. In N. Denzin \& Y. Lincoln (Eds.), The Landscape of Qualitative Research, 4th ed. (pp. 403455). Los Angeles: SAGE.

Milner, H. R. (2013). Why are students of color (still) punished more severely and frequently than White students? Urban Education, 48(4) 483-489.

Milner, H. R., \& Tenore, F. B. (2010). Classroom management in diverse classrooms. Urban Education, 45(5), 560-603.

Roberts, M. A. (2010). Toward a theory of culturally relevant critical teacher care: African American teachers' definitions and perceptions of care for African American students. Journal of Moral Education, 39(4), 449-467.

Skiba, R. J., Ormiston, H., Martinez, S. \& Cummings, J. (2016). Teaching the social curriculum: Classroom management as behavioral instruction. Theory into Practice, 55(2), 120-128. 


\section{RESISTING PUNITIVE SCHOOL DISCIPLINE}

Skiba, R. J., Arredondo, M. I., \& Williams, N. T. (2014). More than a metaphor: The contribution of exclusionary discipline to a school-to-prison pipeline. Equity \& Excellence in Education, 47(4), 546-564.

Skiba, R. J., Horner, R. H., Chung, C., Karega Rausch, M., May, S. L., \& Tobin, T. (2011). Race is not neutral: A national investigation of African American and Latino disproportionality in school discipline. School Psychology Review, 40(1), 85-107.

Skiba, R. J., Michael, R., Nardo, A., \& Peterson, R. (2000). The color of discipline: Gender and racial disparities in school punishment. Bloomington: Indiana Education Policy Center. Spradley, J. (1980). Participant observation. New York: Holt, Rinehart, and Winston.

Ullucci, K. (2009). "This has to be family": Humanizing classroom management in urban schools. Journal of Classroom Interaction, 44(1), 13-28.

U.S. Department of Education Office for Civil Rights. (2014). Civil rights data collection data snapshot: School discipline. Retrieved from http://www2.ed.gov/about/offices/list/ocr/docs/crdc-discipline-snapshot.pdf.

Valencia, R. R. (2010). Dismantling contemporary deficit thinking: Educational thought and practice. New York: Routledge.

Wallace, J. M., Jr., Goodkind, S., Wallace, C. M., \& Bachman, J. G. (2008). Racial, ethnic, and gender differences in school discipline among U.S. high school students: 1991-2005. Negro Educational Review, 59, 47-62.

Weiner, L. (2006). Challenging deficit thinking. Educational Leadership, 64(1), 42-45.

Weinstein, C. S., Curran, M., \& Tomlinson-Clarke, S. (2003). Culturally responsive classroom management: Awareness into action. Theory into Practice, 42(4), 269-276. 
Weinstein, C. S., Tomlinson-Clarke, S., \& Curran, M. (2004). Toward a conception of culturally responsive classroom management. Journal of Teacher Education, 55(1), 25-38.

Woods, R. (2008). When rewards and sanctions fail: A case study of a primary school rulebreaker. International Journal of Qualitative Studies in Education, 21(2), 181-196.

Yin, R. K. (2009). Case study research: Design and methods ( $4^{\text {th }}$ ed.). Thousand Oaks, CA: Sage Publications.

Yosso, T., J. (2005). Whose culture has capital? A critical race theory discussion of community cultural wealth. Race Ethnicity and Education, 8(1), 69-91. 